\title{
Brystsmerter ved anstrengelse: Bakgrunnen for spørsmålene om brystsmerter i norske helseundersøkelser og kjennetegn ved dem som faller positivt ut for mulig angina pectoris
}

\author{
Sidsel Graff-Iversen ${ }^{1}$, Randi Selmer ${ }^{1}$ og Maja-Lisa Løchen ${ }^{2}$ \\ ${ }^{1}$ Nasjonalt folkehelseinstitutt, Postboks 4404 Nydalen, 0403 Oslo \\ ${ }^{2}$ Institutt for samfunnsmedisin, Universitetet $i$ Tromsø, 9037 Tromsø \\ Kontaktperson: Sidsel Graff-Iversen, Nasjonalt folkehelseinstitutt, Postboks 4404 Nydalen, 0403 Oslo \\ Telefon: 23408171 Telefaks: 23408260 e-post: sidsel.graff-iversen@fhi.no
}

\begin{abstract}
SAMMENDRAG
Innledning: Rose Questionnaire er et sett av spørsmål om brystsmerter ved fysisk anstrengelse. Spørsmålene ble utviklet for å fange opp nye tilfelle av angina pectoris i befolkningen. Siden 1972 har en kort versjon blitt brukt i norske helseundersøkelser. Metoden har vært gjenstand for omfattende forskning, spesielt i 1960- og 1970-årene. Det er vist at middelaldrende menn med positivt utfall, kalt Rose angina, har økt dødelighet av koronar hjertesykdom. Spørsmålene brukes fortsatt, men det er tvil om kunnskapen som foreligger er gyldig for middelaldrende kvinner og menn i dag. Denne artikkelen gir oversikt over bakgrunnen for Rose Questionnaire og prevalens av positive utfall. Videre belyses samvariasjon mellom Rose angina og ulike helseforhold, under dette determinanter for koronar hjertesykdom, hos kvinner og menn som ikke samtidig rapporterer om kjent koronar hjertesykdom.

Metode og materiale: Det er brukt to materialer. Det ene består av data fra 40-49-åringer i undersøkelser i Finnmark, Sogn og Fjordane og Oppland 1974-78 og det andre av data fra 40-42-åringer i 11 fylker 199799. Logistisk regresjon ble benyttet for undersøkelse av assosiasjoner.

Resultater: I materialet fra 1970-årene var prevalensen av Rose angina 3,4\% blant menn og 3,9\% blant kvinner, og blant personer uten rapport om kjent koronar hjertesykdom forekom Rose angina hos henholdsvis $2,9 \%$ og 3,4\%. I sistnevnte gruppe var Rose angina forbundet med koronar hjertesykdom i familien hos begge kjønn, med høy samlet infarktrisk hos menn og med overvekt hos kvinner. For begge kjønn var imidlertid hoste og oppspytt den faktoren som viste mest markert assosiasjon til Rose angina hos personer uten kjent koronar hjertesykdom. I materialet fra 1990-årene var prevalensen av Rose angina $2,7 \%$ hos menn og 3,0\% hos kvinner, og henholdsvis $2,5 \%$ og 2,9\% hos dem som ikke hadde kjent koronar hjertesykdom. Blant dem som ut fra sine rapporter var hjertefriske var Rose angina forbundet med overvekt og høy samlet infarktrisk hos begge kjønn. Hos menn skyldtes det siste i hovedsak høye andeler røykere. Selvrapportert astma var den faktoren som i sterkest grad samvarierte med Rose angina, og også angst, tendens til depresjon og smerter i muskler og ledd viste samvariasjon med Rose angina.

Konklusjon: Personer som i 40-årsalderen faller positivt ut for Rose angina uten samtidig å rapportere om kjent koronar hjertesykdom står frem som en gruppe med økt forekomst av flere helseproblemer og risikofaktorer, og i mindre grad som en gruppe med spesifikk risiko for koronar hjertesykdom. For å avklare videre bruk av Rose Questionnaire som indikator for angina pectoris bør Rose angina studeres også $i$ eldre aldersgrupper og det bør gjøres oppfølgingsstudier av sykelighet og dødelighet.
\end{abstract}

Graff-Iversen S, Selmer R, Løchen M-L. Rose Questionnaire in Norwegian health surveys. Nor J Epidemiol 2003; 13 (1): 95-102.

\section{ENGLISH SUMMARY}

Introduction: A short version of Rose Questionnaire, a screening method for angina pectoris, has been used in population surveys in Norway since 1972. Methodological studies were performed mainly in the 1960s and 1970s, and follow-up studies have shown that Rose angina is linked with coronary heart disease (CHD) morbidity and mortality in men. The relations of Rose angina with CHD may, however, differ in women and men and by time period. In this paper the historical background of Rose Questionnaire is outlined, and the prevalence of Rose angina is assessed. Further, the associations of Rose angina with determinants for CHD and other health problems are assessed among subjects free of recognised CHD.

Methods and materials: Two cross-sectional data sets were used: a cohort of women and men aged 40-49 years living in Finnmark, Sogn og Fjordane and Oppland 1974-78, and 40-42 year old subjects in 11 Norwegian counties 1997-99. Logistic regression was used for analyses of associations. 
Results: In the 1970 s the prevalence of Rose angina was 3.4\% among men and 3.9\% among women aged 40-49 years. In subject with no recognised CHD the prevalence was $2.9 \%$ in men and $3.4 \%$ in women. In the "heart healthy" group Rose angina was associated with a family history of CHD, in men with high CHD risk score, and in women with overweight. In both sexes, however, reports of cough and phlegm had stronger association with Rose angina than had other factors that were recorded.

In the $1990 \mathrm{~s}$ the prevalence of Rose angina was $2.7 \%$ in men and $3.0 \%$ in women. In those without recognised CHD the prevalence was $2.5 \%$ and $2.9 \%$. In the latter, "heart-healthy" group Rose angina was linked with overweight and high CHD risk score. In men, the latter association was mostly due to smoking. Self-reported asthma was the factor that showed the strongest association with Rose angina, with odds ratio (OR) around three in both sexes. Further, reports of anxiety, depressive complaints and pain in muscles or joints, registered in the 1990s only, showed positive associations with Rose angina.

Conclusion: Subjects with Rose angina and no report of recognised CHD in their 40s appear as a group with increased prevalence of several health problems, rather than as a high-risk group for CHD only. The future use of Rose Questionnaire in health surveys can be questioned. Studies of Rose angina in older age groups and follow-up studies on morbidity and mortality are warranted.

\section{INNLEDNING}

Rose Questionnaire er et sett av spørsmål om brystsmerter ved anstrengelse og ble utviklet i 1960-årene. Det ble brukt i Oslo-undersøkelsen 1972-73 og Tromsø-undersøkelsen 1974 og er fortsatt i bruk både i Norge og internasjonalt. Hensikten var å screene for ikke tidligere kjent angina pectoris i befolkningen. En hensikt med denne artikkelen er å redegjøre for den historiske bakgrunnen for den norske versjonen. Figur 1 gir en kort oversikt over historikken. Vi har gjort et lite utvalg blant eldre referanser og lagt vekt på nordiske arbeider (1-8).

\section{Betydningen av Rose Questionnaire i forebyggende medisin og epidemiologi}

Spørsmålene om brystsmerter ved anstrengelse er del av en strategi for helsehjelp til den enkelte deltager $i$ norske helseundersøkelser (8-12). Positivt utfall, kalt Rose angina, medfører anbefaling om etterundersøkelse hos lege. For kvinner har dette vært den hyppigste årsaken til slik anbefaling.

Hjerte- og karundersøkelsene i 1974-78 førte til at 2-3\% av personene med Rose angina fikk diagnosen angina pectoris som følge av screening og etterundersøkelse (10). Men legene har ofte funnet grunnlag for utredning, behandling og råd om levevaner til dem som etterundersøkes for brystsmerter (11). Blant 4042-åringer dreier dette seg om 2-3 prosent av deltagere i helseundersøkelsene (12). Etterundersøkelsen får dermed konsekvenser for mange enkeltpersoner.

Spørsmålene om brystsmerter blir i forskningsmessig sammenheng brukt for å definere en gruppe med symptomer på hjertesykdom. Personer uten kjent hjerte- og karsykdom, diabetes, bruk av blodtrykksmedisiner eller Rose angina utgjør en gruppe som det ofte er ønskelig å benytte i oppfølgingsstudier.

Andelene med Rose angina blant 40-åringer er langt høyere enn den antatte forekomsten av koronar hjertesykdom i denne aldersgruppen, og særlig gjelder dette kvinner (10-13). Rose angina har ikke vært brukt som indikator i helseovervåking i Norge.

\section{Problemstilling}

Hensikten med dette arbeidet er å gjennomgå den historiske bakgrunnen for Rose Questionnaire, å rapportere prevalens av Rose angina, og å belyse sammenhengen mellom Rose angina og determinanter for koronar hjertesykdom og andre helseproblemer hos personer uten på forhånd kjent koronar hjertesykdom. Det er videre et mål å belyse eventuelle ulikheter knyttet til kjønn og tidsperiode.

\section{MAteriale OG Metode}

To materialer blir benyttet. Det ene er fra hjerte- og karundersøkelsene i Finnmark, Sogn og Fjordane og Oppland 1974-78 og det andre fra undersøkelser av 40-42-åringer i 11 fylker 1997-99. Alle fremmøtte i aktuelle aldersgrupper med svar på Rose-spørsmålene er inkludert.

Fremmøtet i 1974-78 var i aldersgruppen 35-49 år $89,0 \%$ av menn og 93,5\% av kvinner bosatt i fylkene (10). Materiale og metode er beskrevet av Bjartveit og medarbeidere (8-10). For alle deltagere ble det beregnet en risikoskåre for hjerteinfarkt på grunnlag av totalkolesterol, systolisk blodtykk, røyking og kjønn (10). Beregningen er utviklet av professor Knut Westlund og vil i det følgende kalles Westlund score (WSC).

Til filen med data fra undersøkelsen er koplet opplysninger om utdanning registrert ved Folke- og boligtellingen i 1980. Aldersgruppen 40-49 år benyttes for vårt formål.

Det andre materialet er fra 40-åringsundersøkelser i 11 fylker $1997-99$. Fremmøtet var 54,7\% for menn og $65,6 \%$ for kvinner. Deltagerne fylte $40-42$ det året undersøkelsen startet i de enkelte fylkene. Spørreskjemaet var mer omfattende enn tidligere og inneholdt spørsmål om generell helse, astma og smerter, stivhet $i$ muskler og ledd, mentale helseplager og høyeste utdanning. Midje- og hofteomkrets ble målt, og ikkefastende serum ble undersøkt for HDL-kolesterol og 
Figur 1. Rose Questionnaire om brystsmerter ved anstrengelse.

Standardiserte spørsmål om brystsmerter og smerter i tykkleggen ved anstrengelse ble utarbeidet i 1960-årene av den senere vel kjente professor Geoffrey Rose $(1,2)$. Hensikten var på en enkel måte å identifisere nye tilfelle av angina pectoris og arteriosclerosis obliterans i den generelle befolkningen, hvor man antok at ikke erkjent sykdom var utbredt. Rose fikk dette metodearbeidet pålagt som en av sine første oppgaver som ung forsker.

I det følgende tar vi for oss spørsmålene om brystsmerter. Fra først av var Rose Questionnaire basert på standardisert intervju ved lege (1). Intervjuet inneholdt en oppfordring til å peke på smertens lokalisasjon. Skjema for selvutfylling ble utviklet senere (2-5). De danske Glostrup-undersøkelsene hadde en temmelig ordrett oversettelse av Rose og Blackburns versjon publisert i 1968 (5). Det besto av sju spørsmål, herunder en figur for å angi lokalisasjon, og det var tilføyet et spørsmål om hvorvidt smerten kunne opptre også i ro (6). I befolkningsundersøkelsene i Gøteborg brukte man samme versjon uten tilleggsspørsmålet om smerter i ro (4). En komprimert versjon ble brukt i Oslo-undersøkelsen i 1972-73 og Tromsø 1974 og ble videreført i Finnmark, Sogn og Fjordane og Oppland fra 1974 $(7,8)$. Denne versjonen er brukt i senere undersøkelser frem til i dag. Bortsett fra små språklige justeringer er formuleringene de samme. Parallelt er det stilt spørsmål om deltagerne har eller har hatt hjerteinfarkt, hjerneslag og (kjent) angina pectoris $(7,8)$.

Ordlyden i den norske versjonen var opprinnelig denne:

"Får De smerter eller ubehag i brystet når De: går i bakker, trapper eller fort på flat mark?" (Ja/Nei)

”Dersom De fär smerter eller vondt i brystet ved gange, pleier De da å: Stoppe? Sakne farten? Fortsette i samme takt?" (kryss for alternativet som passer)

"Dersom De stopper eller sakner farten, forsvinner smertene da: Etter mindre enn 10 minutter? Etter mer enn 10 minutter?" (kryss for alternativet som passer)

Positivt utfall for Rose angina ble frem til 1994 definert ved at brystsmerter opptrer under fysisk aktivitet, at smerten medfører at personen stanser eller sakner farten og at smerten så forsvinner etter mindre enn 10 minutter (8).

For å redusere antall positive utfall hos personer med liten risiko for koronar hjertesykdom ble et tilleggsspørsmål om smerter i ro brukt fra 1994. De som svarer ja på dette, får negativt utfall for Rose angina. Ordlyden er slik:

"Kan slike smerter like gjerne opptre mens du er i ro?" (Ja/Nei)

En rekke norske publikasjoner belyser undersøkelsesopplegget, forekomsten av Rose angina i norske fylker, validering av spørsmålene, samvariasjoner i tverrsnittsdata og oppfølging av dødelighet (9-19).

glukose, i tillegg til totalkolesterol og triglyserider. Skåren for samlet infarktrisk er noe forskjellig fra den som ble brukt i 1970-årene (9). Denne skåren kalles i det følgende Infarktrisk (I-risk).

For vårt formål har vi definert høy WSC som WSC $\geq 50$ enheter hos menn og WSC $\geq 7$ enheter hos kvinner og høy I-risk som $\geq 30$ enheter hos menn og $\geq$ 5 enheter hos kvinner. Disse grensene er satt ut fra ønske om å skille ut rundt $25 \%$ i begge tidsperioder og hos begge kjønn.

Vanlig beskrivende statistikk, Chi-kvadrat-test og T-test benyttes, og for utredningen av samvariasjoner er logistisk regresjon blitt brukt. I denne sammenheng er utdanning inkludert som en binær variabel i form av grunnskole versus høyere utdanning. De aktuelle rapporter om sykdom, symptomer og plager er alle inkludert som binære variable. En variabel for selvrapportert angst eller uro er definert som positiv hvis det foreligger rapport om "litt", "en god del" eller "svært mye" plager av angst, nervøsitet eller uro de siste to ukene. Overvekt er definert som KMI $\geq 25 \mathrm{~kg} / \mathrm{m}^{2}$ i datasettet fra 1970 -årene og KMI $\geq 30 \mathrm{~kg} / \mathrm{m}^{2}$ i 1990 årene.

\section{RESUltater}

\section{Rose angina hos personer med og uten rapport om koronar hjertesykdom i 1970-årene}

I alt 17.879 menn og 17.032 kvinner i alder 40-49 år møtte fram til undersøkelse i 1974-78. Av disse falt 608 menn og 663 kvinner positivt ut for Rose angina, slik at prevalens var henholdsvis $3,4 \%$ og $3,9 \%$.

I alt opplyste 372 menn og 123 kvinner at de hadde angina pectoris og/eller gjennomgått hjerteinfarkt, og blant disse forekom Rose angina hos $52,2 \%$ av mennene og 70,7\% av kvinnene. Blant dem som oppga angina pectoris, med eller uten hjerteinfarkt, var de tilsvarende andelene 59,9\% og 71,2\%. Omvendt var andelen som rapporterte å ha kjent koronar hjertesykdom $31,9 \%$ blant menn og $13,1 \%$ blant kvinner med Rose angina. Hos menn med Rose angina rapporterte $25,6 \%$ om angina pectoris, mens denne andelen var $0,6 \%$ hos menn som ikke hadde dette symptomet. Blant kvinner var tilsvarende andeler $11,7 \%$ og $0,2 \%$.

Alle personer med rapport om koronar hjertesykdom ble ekskludert fra videre analyse. Av de gjenværende 17.507 menn og 16.909 kvinner oppga 414 
menn $(2,6 \%)$ og 576 kvinner $(3,4 \%)$ brystsmerter svarende til definisjonen av Rose angina (Figur 1). I Finnmark forekom Rose angina hos 5,0\% av menn og 5,8\% hos kvinner. I Sogn og Fjordane og Oppland var andelene henholdsvis $1,7 \%$ og $3,4 \%$ og $1,6 \%$ og $2,6 \%$ hos menn og kvinner. Forekomsten steg noe med alder hos begge kjønn, for menn fra $1,8 \%$ til 2,8\% og hos kvinner fra $2,8 \%$ til $4,0 \%$.

\section{Karakteristika ved personer med Rose angina i 1970-årene}

Det var en overhyppighet av rapporterte lungesymptomer, symptomer på arteriosclerosis obliterans, bruk av nitroglyserin og blodtrykksmedisin og av hjerteinfarkt hos foreldre og søsken hos personene med Rose angina (Tabell 1). Videre hadde gruppene med Rose angina lavere utdanning, de var mindre fysisk aktive $\mathrm{i}$ fritiden, og hos menn var andelen røykere høyere. Menn og kvinner med Rose angina var oftere sykmeldt eller uføretrygdet enn andre.

Mange av personene med Rose angina var fra Finnmark. Analyse for Oppland og Sogn og Fjordane alene ga omtrent de samme resultatene som vist $\mathrm{i}$ Tabell 1 (ikke vist).

Tabell 2 viser at serumlipider og blodtrykk hos begge kjønn, og særlig hos menn, lå høyere hos personer med Rose angina enn hos andre. Kvinner med Rose angina hadde høyere kroppsmasseindeks (KMI) og høyere andel med KMI $\geq 25 \mathrm{~kg} / \mathrm{m}^{2}$, sammenlignet med kvinner uten slike smerter. Høy WSC forekom klart oftere blant menn med Rose angina enn hos andre, mens det var mindre forskjell hos kvinner.

Forholdsvis mange av dem som falt positivt ut for Rose angina hadde samtidig positive utfall for flere av faktorene i Tabell 1 og Tabell 2. Andel med både lungesymptomer og høy WSC var 19,9\% hos menn og $8,7 \%$ hos kvinner med Rose angina, mot henholdsvis $6,1 \%$ og $2,9 \%$ hos personer uten slike brystsmerter. Andelene med både lungesymptomer og overvekt $\left(\mathrm{KMI} \geq 25 \mathrm{~kg} / \mathrm{m}^{2}\right)$ var $18,1 \%$ og $7,4 \%$ hos menn og $9,9 \%$ og $2,7 \%$ hos kvinner.

\section{Sammenheng mellom Rose angina og andre helseforhold $i$ 1970-årene}

Tabell 3 viser andeler med Rose angina ved ulike andre helseforhold og resultater av logistisk regresjon med Rose angina som avhengig variabel. Analysen er gjort for hver enkelt faktor alene, og det er justert for alder, fylke (Finnmark) og utdanning. Spesielt blant personer med lungesymptomer var andelene med Rose angina høye med en justert odds ratio (OR) rundt tre (Tabell 3). Det samme gjaldt for koronar hjertesykdom i familien hos begge kjønn, med justerte OR rundt to. Høy WSC viste samvariasjon med Rose angina hos menn med justert OR på to, mens det hos kvinner var svakere sammenheng. Overvekt var mer markert assosiert med Rose angina hos kvinner enn hos menn. Også tidlig menopause viste positiv sammenheng med Rose angina.

I en logistisk regresjonsanalyse med lungesymptomer, familiehistorie, høy WSC, overvekt og for kvinner tidlig menopause inkludert sammen med de foran

Tabell 1. Karakteristika ved kvinner og menn uten og med Rose angina i alder 40-49 år i Finnmark, Sogn og Fjordane og Oppland 1974-78. Prosent.

\begin{tabular}{|c|c|c|c|c|c|c|}
\hline & \multicolumn{3}{|c|}{ Menn } & \multicolumn{3}{|c|}{ Kvinner } \\
\hline & \multicolumn{2}{|c|}{ Rose angina } & \multirow[b]{2}{*}{ p-verdi } & \multicolumn{2}{|c|}{ Rose angina } & \multirow[b]{2}{*}{ p-verdi } \\
\hline & $\begin{array}{c}\text { Nei } \\
\mathrm{N}=17.093\end{array}$ & $\begin{array}{c}\mathrm{Ja} \\
\mathrm{N}=414\end{array}$ & & $\begin{array}{c}\text { Nei } \\
\mathrm{N}=16.333\end{array}$ & $\begin{array}{c}\mathrm{Ja} \\
\mathrm{N}=576\end{array}$ & \\
\hline \multicolumn{7}{|l|}{ Demografiske og sosiale faktorer } \\
\hline Fra Finnmark & 21,8 & 46,6 &, 00 & 20,4 & 35,1 &, 00 \\
\hline Grunnutdanning inntil 7 år & 70,5 & 83,3 &, 00 & 77,7 & 83,0 & 01 \\
\hline Høgskole/universitetsutdanning & 7,7 & 3,6 &, 01 & 4,4 & 3,1 &, 15 \\
\hline Sykmeldt eller uføretrygdet & 6,6 & 16,7 &, 00 & 5,5 & 14,2 &, 00 \\
\hline Arbeidsledig & 3,5 & 4,8 & 15 & 2,3 & 2,6 &, 58 \\
\hline Husarbeid hovedyrke & 0,4 & 2,0 &, 00 & 72,2 & 76,6 &, 02 \\
\hline \multicolumn{7}{|l|}{ Helsemessige forhold } \\
\hline Hoste og/eller oppspytt & 15,7 & 37,0 &, 00 & 7,3 & 21,3 & 00 \\
\hline Symptomer på arteriosclerosis obliterans & 1,1 & 14,0 & 00 & 1,7 & 15,5 & 00 \\
\hline Bruker nitroglyserin & 0,1 & 2,4 & 00 & 0,1 & 1,4 & 00 \\
\hline Bruker blodtrykksmedisin & 3,2 & 9,0 &, 00 & 4,5 & 13,2 & 00 \\
\hline Hjerneslag & 0,2 & 0,2 &, 83 & 0,2 & 1,2 &, 00 \\
\hline Diabetes mellitus & 0,8 & 2,4 &, 00 & 0,6 & 0,5 &, 86 \\
\hline Hjerteinfarkt i familien & 25,9 & 44,2 &, 00 & 29,3 & 43,4 &, 00 \\
\hline Menopause eller mulig menopause & & & & 24,7 & 33,3 &, 00 \\
\hline \multicolumn{7}{|l|}{ Helseatferd } \\
\hline Dagligrøykere & 52,4 & 67,6 &, 00 & 34,8 & 35,9 &, 56 \\
\hline Tidligere røykere & 22,9 & 19,8 &, 14 & 11,3 & 13,0 & 20 \\
\hline Fysisk inaktive $\mathrm{i}$ fritiden & 18,4 & 27,6 &, 00 & 22,7 & 34,9 &, 00 \\
\hline
\end{tabular}


nevnte justeringsfaktorene ble alle OR noe lavere enn vist $\mathrm{i}$ Tabell 3. For lungesymptomer var OR 2,16 (95\% KI 1,48-2,35) hos menn og 3,03 (95\% KI 2,46-3,74) hos kvinner. Hos kvinner var det ingen signifikant assosiasjon mellom Rose angina og WSC når denne modellen ble brukt. Hos menn var høy WSC positivt assosiert med Rose angina $(\mathrm{OR}=1,54 ; 95 \% \mathrm{KI}$ 1,28-1,84). Ved justering for røyking, som inngår $\mathrm{i}$ WSC, var assosiasjonen omtrent uforandret $(\mathrm{OR}=1,59$; 95\% KI 1,31-1,92).

Lav utdanning og tilhørighet i Finnmark fylke var positivt assosiert med Rose angina hos begge kjønn.

\section{Rose angina hos 40-42-åringer $i$ 1990-årene}

Fra 1997 til 1999 ble i alt 111.124 personer i 11 fylker invitert til 40-åringsundersøkelse. Av disse møtte 66.744 personer, 30.913 menn og 35.831 kvinner, som utgjorde henholdsvis $54,7 \%$ og $65,6 \%$ av de inviterte. Rose angina er for vårt formål definert uten bruk av tilleggsspørsmålet om smertene kan forekomme også i ro.

Blant dem som rapporterte at de hadde koronar hjertesykdom (angina pectoris eller hjerteinfarkt) falt $26,3 \%$ av mennene og $24,5 \%$ av kvinnene positivt ut for Rose angina, og blant dem som rapporterte angina pectoris var andelene 30,4 og 26,9\%. Andelene med rapport om kjent angina pectoris blant dem som hadde Rose angina var $6,8 \%$ hos menn og $2,2 \%$ hos kvinner. Blant dem som falt negativt ut for Rose angina, oppga henholdsvis $2,0 \%$ og $0,2 \%$ at de hadde angina pectoris. De $\mathrm{i}$ alt 353 personene som rapporterte om koronar hjertesykdom ble ekskludert fra videre analyse.
Av de resterende 30.658 menn og 35.733 kvinner falt 774 menn (2,5\%) og 1053 kvinner (2,9\%) inn under den opprinnelige definisjonen av Rose angina, og det var små forskjeller mellom fylkene. Blant menn lå Møre og Romsdal høyest, med 3,6\% og Oppland lavest med 2,2\%. Blant kvinner var Rose angina mest utbredt i Buskerud, med 3,6\% og minst i Sogn og Fjordane, med 1,6\%. I Nordland, som var eneste nordnorske fylke, var forekomsten $2,6 \%$ hos menn og 3,0\% hos kvinner.

\section{Kvinner og menn med Rose angina $i$ 1990-årene}

En oversikt over karakteristika ved 40-42-åringer med og uten Rose angina viste overhyppighet av lav utdanning, hjerteinfarkt i familien, bruk av blodtrykksmedisin, fysisk inaktivitet og tidlig menopause hos kvinner ved Rose angina. Gjennomsnittlig høyde hos kvinner var noe lavere ved Rose angina enn hos andre. Blant personer med Rose angina røykte $51 \%$ av menn og $48 \%$ av kvinner, mens tilsvarende andeler hos de øvrige var 34\% og 37\%. Angst eller uro ble rapportert av $48,7 \%$ av menn og 55,6\% av kvinner som falt positivt ut for Rose angina, mot $24,2 \%$ av menn og $27,0 \%$ av kvinner uten slike brystsmerter.

Gjennomsnittsnivåene for KMI, serum triglyserider og serum glukose lå noe høyere hos personer med Rose angina enn hos andre. Gjennomsnittsverdiene for KMI var $27,3 \mathrm{~kg} / \mathrm{m}^{2}$ hos menn og $27,2 \mathrm{~kg} / \mathrm{m}^{2}$ hos $\mathrm{kvin}-$ ner med Rose angina, mens menn og kvinner uten brystsmerter hadde nivåene $26,5 \mathrm{~kg} / \mathrm{m}^{2}$ og $25,1 \mathrm{~kg} / \mathrm{m}^{2}$. Forskjellene i gjennomsnittlige triglyseridnivåer var 0,3 mmol/1 hos menn og 0,35 mmol/l hos kvinner.

Tabell 2. Risikofaktorer for hjerte- og karsykdom hos menn og kvinner uten og med Rose angina i alder 40-49 år i Finnmark, Sogn og Fjordane og Oppland 1974-78.

\begin{tabular}{|c|c|c|c|c|c|c|}
\hline & \multicolumn{3}{|c|}{ Menn } & \multicolumn{3}{|c|}{ Kvinner } \\
\hline & \multicolumn{2}{|c|}{ Rose angina } & \multirow[b]{2}{*}{$\begin{array}{c}\text { Differanse } \\
(95 \% \mathrm{KI})\end{array}$} & \multicolumn{2}{|c|}{ Rose angina } & \multirow[b]{2}{*}{$\begin{array}{c}\text { Differanse } \\
(95 \% \mathrm{KI})\end{array}$} \\
\hline & $\begin{array}{c}\text { Nei } \\
\mathrm{N}=17.093\end{array}$ & $\begin{array}{c}\mathrm{Ja} \\
\mathrm{N}=414\end{array}$ & & $\begin{array}{c}\text { Nei } \\
\mathrm{N}=16.333\end{array}$ & $\begin{array}{c}\mathrm{Ja} \\
\mathrm{N}=576\end{array}$ & \\
\hline \multicolumn{7}{|l|}{ Gjennomsnittsverdier: } \\
\hline Alder, år & 44,6 & 45,0 & $0,4(0,2-0,7)$ & 44,7 & 45,0 & $0,3(0,1-0,6)$ \\
\hline Høyde, $\mathrm{cm}$ & 174,9 & 173,5 & $-1,4(-2,1--0,8)$ & 162,1 & 161,3 & $-0,8(-1,2--0,2)$ \\
\hline KMI, $\mathrm{kg} / \mathrm{m}^{2}$ & 25,2 & 25,7 & $0,5(0,2-0,8)$ & 25,1 & 26,4 & $1,3(0,9-1,6)$ \\
\hline Serum totalkolesterol, $\mathrm{mmol} / \mathrm{l}$ & 6,16 & 6,84 & $0,7(0,5-0,9)$ & 6,15 & 6,43 & $0,3(0,1-0,4)$ \\
\hline Serum triglyserider, $\mathrm{mmol} / 1$ & 1,96 & 2,21 & $0,3(0,1-0,4)$ & 1,37 & 1,50 & $0,1(0,1-0,2)$ \\
\hline Serum glukose, mmol/1 & 5,98 & 6,00 & $0,0(-0,2-0,1)$ & 5,81 & 5,71 & $-0,1(-0,2-0,0)$ \\
\hline $\mathrm{SBT}, \mathrm{mm} \mathrm{HG}$ & 129,9 & 137,2 & $7,3(3,9-10,6)$ & 128,8 & 132,1 & $3,3(0,7-5,9)$ \\
\hline $\mathrm{DBT}, \mathrm{mm} \mathrm{HG}$ & 81,2 & 86,9 & $5,7(3,5-7,7)$ & 79,2 & 82,7 & $3,5(2,0-5,1)$ \\
\hline WSC, enheter & 42,9 & 75,9 & $33,0(26,5-39,6)$ & 6,3 & 8,1 & $1,8(1,0-2,6)$ \\
\hline \multicolumn{7}{|l|}{ Median: } \\
\hline WSC, enheter & 23,1 & 41,9 & & 3,5 & 4,0 & \\
\hline \multicolumn{7}{|l|}{$\%$-andel over grenseverdi: } \\
\hline $\mathrm{WSC} \geq 50$ enheter & 24,9 & 46,3 & $21,4(17,1-25,9)$ & & & \\
\hline WSC $\geq 7$ enheter & & & & 25,9 & 32,0 & $6,1(2,4-9,8)$ \\
\hline $\mathrm{KMI} \geq 25 \mathrm{~kg} / \mathrm{m}^{2}$ & 47,1 & 50,3 & $3,2(-1,9-8,3)$ & 41,5 & 54,3 & $12,8(8,5-16,9)$ \\
\hline
\end{tabular}


Gjennomsnittlig midjeomkrets var 1,9 (95\% KI 1,3-2,6) cm større hos menn og 5,0 (95\% KI 4,3-5,6) cm større hos kvinner med Rose angina.

Hos begge kjønn lå gjennomsnittsverdien for glukose $0,16 \mathrm{mmol} / 1$ høyere ved Rose angina. Gjennomsnittsnivået for HDL-kolesterol var henholdsvis 0,05 $\mathrm{mmol} / \mathrm{l}$ og 0,12 mmol/l lavere hos menn og kvinner med Rose angina enn hos andre. Alle disse forskjellene var statistisk signifikante $(\mathrm{p}<0,001)$.

Nivået for totalkolesterol var så vidt høyere ved Rose angina $(p<0,01)$, og også blodtrykket varierte lite. Men andelene som enten brukte blodtrykksmedisin eller hadde SBT $\geq 140 \mathrm{mmHg}$ eller DBT $\geq 90$ $\mathrm{mmHg}$ var noe høyere, $25 \%$ og $18 \%$ hos menn og kvinner med Rose angina, mot $23 \%$ og $10 \%$ hos personer uten slike smerter.

Høy I-risk forekom hos 34,6\% av menn og 39,5\% av kvinner med Rose angina og hos 20,0 og 26,0\% av menn og kvinner uten dette symptomet, og forskjellene var statistisk signifikante $(\mathrm{p}<0,001)$.

\section{Rose angina og andre helseforhold $i$ 1990-årene}

Tabell 4 viser andeler med Rose angina blant 40-42 år gamle menn og kvinner med ulike helsetilstander. Disse andelene var høyest blant dem som oppga å ha astma og var også høye blant personer med mentale helseplager og muskelsmerter, sammenlignet med andelene i materialet som helhet (tabell 4). Ved logistisk regresjon, hvor hver enkelt faktor ble analysert med justering for utdanning, var astma, angst, tendens til depresjon, muskelsmerter, høy I-risk, overvekt, stor midjeomkrets og rapport om hjerteinfarkt hos foreldre eller søsken positivt forbundet med Rose angina (Tabell 4).

Logistisk regresjon ble så utført med selvrapportert astma, angst og/eller uro, høy I-risk, overvekt, koronar hjertesykdom i familien, utdanning og hos kvinner også tidlig menopause i samme modell. Alle faktorene som inngår i tabell 4 fikk da noe lavere OR enn vist $i$ denne tabellen. Astma og angst/uro kom ut med de sterkeste assosiasjonene med Rose angina, hos begge kjønn med OR rundt tre. For kvinner var OR for Rose angina ved høy I-risk 1,46 (95\% KI 1,27-1,68) mens OR for menn var 1,58 (95\% KI 1,35-1,84). Justering for røyking, som inngår i I-risk, førte til at OR for Rose angina ble vesentlig redusert hos menn $(\mathrm{OR}=1,20 ; 95 \%$ CI 1,01-1,43), mens assosiasjonen hos kvinner ble redusert i mindre grad $(\mathrm{OR}=1,37 ; 95 \%$ CI 1,17-1,61).

Hjerteinfarkt i familien viste svak, grensesignifikant assosiasjon til Rose angina hos begge kjønn. Lav utdanning var signifikant positivt forbundet med Rose angina hos begge kjønn, med OR for Rose angina på 1,56 hos menn og 1,62 hos kvinner.

For å få et inntrykk av hvordan assosiasjonene ville være i materialene som helhet, med dem som hadde kjent hjertesykdom inkludert, tok vi for oss dette i materialet fra 1990-årene. Egenrapport om koronar hjertesykdom var assosiert med Rose angina med OR nærmere 10 hos menn og rundt fem hos kvinner når faktorene nevnt foran var inkludert. Astma og angst/ uro var fortsatt forbundet med Rose angina med OR rundt tre, og også de øvrige faktorene viste omtrent de samme assosiasjonene som er nevnt foran.

\section{DISKUSJON}

Rose angina var vanlig blant personer som opplyste at de hadde koronar hjertesykdom, og i 1970-årene rapporterte forholdsvis høye andeler av menn og kvinner med Rose angina at de hadde angina pectoris. Disse andelene var vesentlig lavere i materialet fra 1990årene.

Blant dem som ikke rapporterte om kjent koronar hjertesykdom forekom Rose angina hos omkring 3\% i begge materialene vi har brukt. I 1997-99 var prevalensen nesten like høy blant de selvrapportert "hjertefriske" som i materialene som helhet. Videre er alderen høyest i materialet fra 1970-årene, og risikofaktorer for og dødelighet av hjerteinfarkt har gått ned de siste 30 årene $(13,18)$. Tar man dette $i$ betraktning er prevalensen av Rose angina påfallende høy i materialet fra 1997-99, i den grad man vurderer Rose angina som en indikator for koronar hjertesykdom.

Forekomsten av Rose angina var også påfallende høy i Finnmark. Spørsmålet er om dette i noen grad skyldes språklige eller andre kulturelle forhold. Et forholdsvis høyt nivå av angina pectoris i Finnmark i

Tabell 3. Andel personer med Rose angina blant 40-49-åringer 1974-78 ved ulike helseforhold og OR for Rose angina ved de samme. N=17.507 menn og 16.909 kvinner.

\begin{tabular}{|c|c|c|c|c|c|c|c|c|}
\hline & \multicolumn{4}{|c|}{ Menn, andel med og OR for Rose angina } & \multicolumn{4}{|c|}{ Menn, andel med og OR for Rose angina } \\
\hline & $\%$ & OR, ujustert & OR, justert* & $95 \% \mathrm{KI}$ & $\%$ & OR, ujustert & OR, justert* & $95 \% \mathrm{KI}$ \\
\hline Lungesymptomer & 5,6 & 3,31 & 2,95 & $2,4-3,6$ & 9,5 & 3,51 & 3,35 & $2,7-4,1$ \\
\hline Høy WSC ** & 4,3 & 2,56 & 2,01 & $1,6-2,5$ & 4,3 & 1,35 & 1,18 & $1,0-1,4$ \\
\hline Overvekt*** & 2,6 & 1,18 & 1,19 & $1,0-1,5$ & 4,5 & 1,72 & 1,62 & $1,4-1,9$ \\
\hline Familiehistorie & 4,1 & 2,39 & 2,28 & $1,9-2,8$ & 5,1 & 1,91 & 1,85 & $1,6-2,2$ \\
\hline Menopause & & & & & 4,6 & 1,56 & 1,47 & $1,2-1,8$ \\
\hline Hele materialet & 2,6 & & & & 3,4 & & & \\
\hline
\end{tabular}

* $\quad$ justert for alder, fylke (Finnmark) og utdanning

** WSC $\geq 50$ enheter hos menn og $\geq 7$ enheter hos kvinner

*** $\quad \mathrm{KMI} \geq 25 \mathrm{~kg} / \mathrm{m}^{2}$ 
1970-årene kan riktignok ventes ut fra risikofaktorer og dødelighet $(10,13)$.

Blant menn uten selvrapportert hjertesykdom fant vi, som ventet ut fra annen kunnskap, positiv assosiasjon mellom høy skår for infarktrisk og Rose angina (8,10,14-19). Av faktorene som inngår i skårene var totalkolesterol og blodtrykk viktige i 1970-årene, mens røyking var viktig for assosiasjonen med Rose angina $i$ 1990-årene. Hos kvinner var det ingen klar sammenheng mellom Rose angina og høy infarktrisk i 1970årene, men assosiasjonen var positiv i 1990-årene. I materialet fra 1990-årene hadde også overvekt sammenheng med Rose angina, og hos menn var dette nytt i forhold til 1970-årene.

Symptomer fra lungene var den faktoren som viste mest markert samvariasjon med Rose angina hos personer som ikke rapporterte om kjent hjertesykdom. Denne sammenhengen var konsistent tilstede hos begge kjønn og i begge tidsperiodene. Rapport om angst eller uro, depressive helseplager og smerter i muskler og ledd viste markerte assosiasjoner med Rose angina $i$ materialet fra 1997-99. Her kan vi ikke sammenligne med eldre data.

Vi har tatt for oss aldersgrupper hvor koronar hjertesykdom har lav prevalens $(10,12)$. Ikke erkjent angina pectoris må antas å forekomme hyppigere med økende alder, slik at Rose Questionnaire kan være en bedre metode for å oppdage koronar hjertesykdom hos eldre enn hos personer i 40-årsalderen.

\section{Kan lungesykdom, overvekt og angst gi brystsmerte ved anstrengelse?}

Sammenhengen mellom Rose angina og lungesymptomer var ikke noe uventet funn. Westlund fant dette $\mathrm{i}$ data fra 1977-83 hvor mange av personene i vårt materiale inngår (19). I en liten studie fra en lungeklinikk er det funnet bronkial hyperreaktivitet hos en stor andel av pasienter som var utredet for hjertesykdom på grunn av brystsmerter (20).
Begrepene "smerter eller ubehag i brystet" er brukt i det innledende Rose-spørsmålet. Det ligger nær å anta at lungeproblemer i seg selv kan gi ubehag ved fysisk aktivitet. Også overvekt kan representere et ubehag som føles lokalisert til brystet.

Også angst kan oppleves som ubehag i brystet. Det har vært hevdet at minst en tredjedel av pasienter med brystsmerter og negativt funn ved hjerteutredning har panikkangst som sin primære lidelse (21). I tillegg har man funnet at generalisert angstlidelse, depresjon, somatoform smertelidelse, mage- og tarmsykdommer, lungeemboli, lungebetennelse og muskel- og skjelettlidelser i form av brystveggsyndrom, osteokondritt og cervikal ribbe kan forårsake angina-lignende brystsmerter (21).

Assosiasjonene vi har funnet passer godt med de nevnte funnene fra klinikken. Men brystsmerter, lungesymptomer, mentale helseplager og overvekt kan også forekomme samtidig uten at det foreligger noe årsaksforhold.

\section{Svakheter i metoden}

Vi kjenner ikke tidsrelasjonen mellom Rose angina og de forholdene vi har studert. Fysisk inaktivitet, overvekt, arbeidsuførhet, angst, depresjon og muskelsmerter kan, for alt vi vet, være følger av brystsmertene eller inngå sammen med brystsmerter i sammensatte syndrom.

Data som er hentet fra samme spørreskjema har som feilkilde at det foreligger en viss intern avhengighet, slik at bekreftende svar på ett spørsmål kan ledsages av bekreftende svar på et annet. Denne feilkilden kan ha gitt sterkere sammenhenger mellom de ulike helseplager enn hva uavhengige data ville vist. Et forhold som taler mot at dette er en viktig feilkilde her, er at positivt utfall for Rose angina innebærer varierende svar på tre forskjellige spørsmål (Figur 1).

Fremmøtet til undersøkelsene var nærmere 90 prosent i 1970-årene og rundt 60 prosent i 1990-årene.

Tabell 4. Andel med Rose angina blant 40-42-åringer 1997-99 med ulike helseforhold og OR for Rose angina ved de samme. $\mathrm{N}=30.658$ menn og 35.733 kvinner.

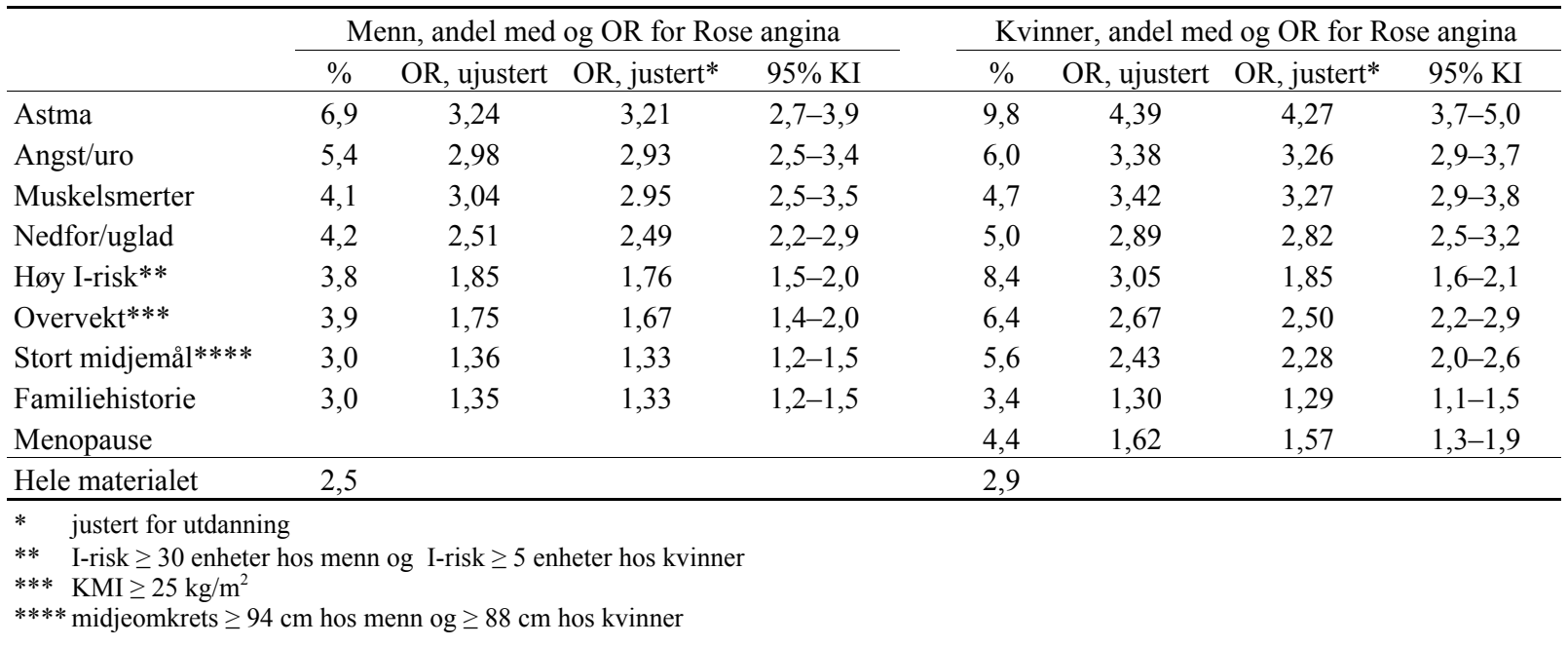


Hvis en helseplage som Rose angina eller forhold forbundet med dette symptomet har betydning for fremmøte, kan våre data gi et feilaktig bilde av prevalens. Det er mindre sannsynlig at samvariasjonene mellom Rose angina og andre helseforhold varierer med fremmøte.

\section{KONKLUSJON}

Både i 1970-årene og i 1990-årene står menn og kvinner med Rose angina frem som grupper med økt risiko for flere kroniske sykdommer, og har ikke preg av å være risikogrupper for koronar hjertesykdom alene. Bildet kan være et annet i eldre aldersgrupper. Både internasjonalt og i Norge er det tvil om den fortsatte bruken av Rose Questionnaire. Vår undersøkelse avkrefter ikke en slik tvil, men gir heller ikke all kunnskap som trengs. Spesielt er det ønskelig å vite mer om Rose angina hos eldre og om sykdom og dødsårsaker hos personer med Rose angina.

Vi takker Kjell Bjartveit, Per G. Lund-Larsen og staben ved tidligere Statens helseundersøkelser for deres arbeid i planlegging og gjennomføring av undersøkelsene.

\section{REFERANSER}

1. Rose G. The diagnosis of ischemic heart pain and intermittent claudication in field surveys. Bull WHO 1962; 27: 645-57.

2. Rose G, McCartney P, Reid DD. Self-administration of a questionnaire on chest pain and intermittent claudication. Br J Prev Soc Med 1977; 31: 42-8.

3. Zeiner-Henriksen T. Comparison of personal interview and postal inquiry methods for assessing prevalence of angina and possible infarction. J Chron Dis 1972; 25: 433-40.

4. Elmefeldt D. Hjärtinfarkt i Göteborg 1968-1970. Morbiditet og mortalitet. Karakteristika för överlevande män i jämnförelse med den manliga befolkningen. Kungsbacka: Elanders boktryckeri aktiebolag, 1974.

5. Rose GA, Blackburn H. Cardiovascular Survey Methods. Geneva: World Health Organisation Monograph Series 56, 1968.

6. Hagerup L, Eriksen M, Schroll M, Hollnagel H, Agner E, Larsen S (red). The Glostrup Population Studies Collection of epidemiologic tables. Reference values for use in cardiovascular population studies. Holstebro: The Danish Heart Foundation, ISBN 87-981007-1-8.

7. Leren P, Askevold EM, Foss OP, Frøili A, Grymyr D, Helgeland A, et al. The Oslo Study. Cardiovascular disease in middle-aged and young Oslo men. Acta Med Scand 1975; Suppl 588.

8. Bjartveit K, Foss PO, Gjervig T, Lund-Larsen PG. The cardiovascular disease study in Norwegian counties. Background and organization. Acta Med Scand 1985; Suppl 634: 1-70.

9. Bjartveit K, red. Håndbok for hjerte-karundersøkelsen. 40-årings-prosjektet. Oslo: Statens helseundersøkelser, 1987.

10. Bjartveit K, Foss OP, Gjervig T. The cardiovascular disease study in Norwegian counties. Results from the first screening. Acta Med Scand 1983; Suppl. 675.

11. Bjerke Karlsen K, Graff-Iversen S, Knapskog A. Allmennpraktikerens tiltak ved høy risiko for hjerte- og karsykdom. Informasjon fra meldekort etter 40-åringsundersøkelsen i Telemark 1992. Tidsskr Nor Lageforen 1994; 114: 3427-30.

12. Graff-Iversen S (red.) Hjertesaken. Rapport om hjerte-karundersøkelsen. Helseundersøkelsen i Buskerud 1999, 3. runde. Oslo: Statens helseundersøkelser, 2000. www.fhi.no/publ/rapporter.

13. Bjartveit K, Wøien G. Risikofaktorer for hjerte-karsykdom i Norge. Oslo: Statens helseundersøkelser, 1997.

14. Zeiner-Henriksen T. Cardiovascular disease symptoms in Norway - a study of prevalence and a mortality follow-up. J Chron Dis 1971; 24: 553-67.

15. Zeiner-Henriksen T. Six-year mortality related to cardiorespiratory symptoms and environmental risk factors in a sample of the Norwegian population. J Chron Dis 1976; 29: 15-33.

16. Tretli S, Lund-Larsen PG, Foss OP. Reliability of questionnaire information on cardiovascular disease and diabetes: cardiovascular disease study in Finnmark county. J Epidemiol Community Health 1982; 36: 269-73.

17. Tretli S, Lund-Larsen PG, Bjartveit K. Questionnaire prevalence of cardiovascular disease and symptoms, changes after a period of three years. The cardiovascular disease study in Finnmark county, Norway. ISM skriftserie 1983; nr. 6: 123-41.

18. Tverdal A. A mortality follow-up of persons invited to a cardiovascular disease study in five areas in Norway. Oslo: Statens helseundersøkelser, 1989.

19. Westlund K. The cardiovascular disease study in Norwegian counties. Results from the second screening. Oslo: Statens helseundersøkelser, 1988.

20. Kiss D, Veegh W, Schragel D, Bachl C, Stöllberger C, Sertl K. Bronchial asthma causing symptoms sugges tive of angina pectoris. Eur Respir J 2003; 21: 473-7.

21. Dammen T. Psykologiske faktorer ved ikke-kardiale brystsmerter. Tidsskr Nor Laegeforen 2002; 122: $1391-5$. 